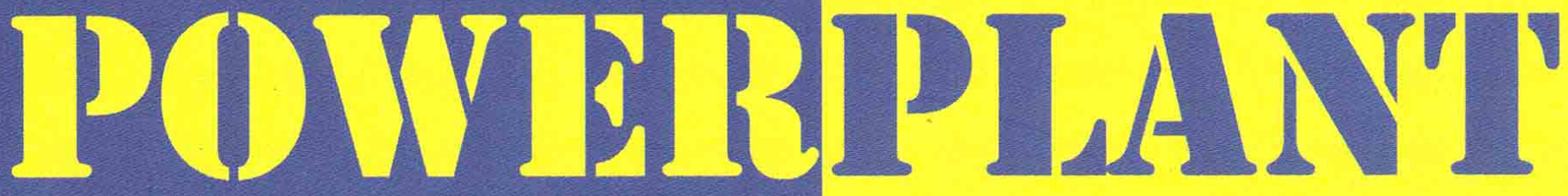

Nofirman:

Yusuf Rasyid

Vendy Antono;

Win Alfalah;

Rizky Windani

Eko Sulistiyo:

Utami Wahyuningsih:

M. Arif Rahman Sutisna

Sahlan

Vendy Antono;

Arief Suardi Nur Chairat;

Muhammad Husnuddin

Prayudi:

Roswati Nurhasanah

Hendri;

Suhengki:

Amru Fathony Lubis

Sri Yayi:

Jumiati;

Intan Ratna Sari Yanti
Pengaruh Kegagalan Terhadap Kinerja Chiller

Analisa Kegagalan Platen Tube SUperheater PLTU Teluk Sirih

Analisis Head Losses Pada Penstok Unit III Di Perum Jasa Tirta II Unit Jasa Pembangkit PLTA Ir. H.Djuanda

Kajian Terkait Industri Material HANKAM Dan

Kebencanaan Dari Sisi Pasar

Analisa Kerusakan Roda Gigi Cacing Pada Gearbox Air Preheater PLTU UJP Banten 3 Lontar Unit 1

Studi Eksperimental Kinerja Clod Strorage Mini dengan Refrigerant R2 dan R404A

Pengaruh Fouling Terhadap Laju Perpindahan Panas Pada Superheater Boiler CFB PLTU Sebalang

Pengaruh Jenis Pengetahuan Dan Kecakapan Terhadap Kemampuan Menulis Bahasa Inggris Pada Mahasiswa Teknik Mesin Sekolah Tinggi Teknik PLN

\begin{tabular}{|c|c|c|c|c|c|c|}
\hline$\|\mid\|$ & & SE & OLAH & VGGI TEKI & PL & \\
\hline
\end{tabular}




\title{
PENGARUH JENIS PENGETAHUAN DAN KECAKAPAN TERHADAP KEMAMPUAN MENULIS BAHASA INGGRIS PADA MAHASISWA TEKNIK MESIN SEKOLAH TINGGI TEKNIK PLN
}

\author{
Sri Yayi, S.Pd., M.Pd \\ Jurusan S1 Teknik Mesin, Sekolah Tinggi Teknik -PLN \\ Email : sriyayi24@yahoo.com \\ Dra. Jumiati, M.Pd \\ Jurusan S1 Teknik Mesin, Sekolah Tinggi Teknik - PLN \\ Email : Jumistt@gmail.com \\ Dra. Intan Ratna SariYanti, M.M \\ Jurusan S1 Teknik Mesin, Sekolah Tinggi Teknik - PLN \\ Email : intan.yanti@gmail.com
}

\begin{abstract}
The purpose of this study was to investigate the effects of genre knowledge and sentence structure toward dtudent's writing skill in recount text in STT PLN Jakarta.In this research, the writer uses survey methodology with approach to correlation.The result of study identivies : 1) There is an effect of significant genre knowledge and sentence structure toward student's writing skill in recaoun text with coefficient correlation multiple Ry $12=0.811$.Genre knowledge and sentence structure to give $65.8 \%$ toward variation student's writing skill in recount text via similarity multiple regression $Y=$ $34.466+0.793 \times 1+0.602 \times 2$ which significant to standard 0.05 . In relation to result of the recearch significant exam is able to $F$ account $=35.563>F$ table $=3.25 .2)$ There is an effect which significant genre knowledge toward student's writing skill in recauntext variable genre knowledge the way of effecttive give $64.3 \%$ toward variation student's writing skill in recaunt text. The result of the researce significant is able to taccount (4.836) >t table (1.69) to standart real $5 \%$. 3 There is an effects significant between sentence structure student's writing skill in recaount text .Variable sentence structure the of evective give $35.7 \%$ toward variation student's skill in recount text. The result of significant is able to taccount (3.058) < t table (1.69) to standard real $5 \%$.
\end{abstract}

Keywords : genre knowledge, sentence structure,writing skill.

\section{Pendahuluan}

Bahasa Inggris adalah bahasa yang sangat penting digunakan bagi semua Negara, masyarakat sekretaris pembisnis karyawan mahasiswa serta smp,smu ataupun instansi lain. Dan sangat penting untuk berkomunikasi dengan Negara yang sedang berkembang dan mudah untuk mencari pekerjaan. Seseorang yang bisa menguasai bahasa Inggris baik tulisan ataupun bicara tidak akan sulit mendapat pekerjaan. Pengaruh jenis pengetahuan dan kecakapan terhadap kemampuan menulis Bahasa Inggris STT PLN.

Kegiatan penulis ini dilaksanakan oleh para dosen dosen Teknik Mesin dan mahasiswa STT PLN dibidang pendidikan. Hal ini akan mencerdaskan dari pengembangan pendidikan dalam menggunakan Bahasa Inggris yang tulisan maupun komunikasi yang menggunakan susunan kalimat yang benar. Jenis pengetahuan sebagai aktivitas yang mempunyai cita-cita yang tinggi yang dimaksud adalah Kebudayaan Bahasa Inggris ( Martin 1997 ) dalam penyusunan. Sebagai Dosen / Guru di kampus,di sekolah, di kursus ataupun instansi- instansi lain. Ide penelitian ini mendorong mahasiswa untuk berpikir masa depan dengan tambahan kecakapan terhadap Bahasa Inggris. Jadi peneliti berfokus sejauh mana mahasiswa Teknik Mesin STT PLN bisa menguasai Bahasa Inggris tulisan ataupun komunikasi yang benar. 
Apakah kurang waktunya dalam kurikulum .Apakah nyata bahwa tamatan Teknik Mesin STT PLN bisa bicara Bahasa Inggris dan dalam menulis susunan kalimat yang benar. Kami semua tahu hampir semua mahasiswa tidak bisa bicara Bahasa Inggris dan dalam menulis Bahasa Inggris. Prestasi dalam mempelajari Bahasa Inggris sangat kecil minatnya baik tulisan ataupun komunikasi dalam berbahasa Inggris karena tidak menguasai vocab menyusun kalimat dalam ilmu bahasa.

Masalahnya nyata bahwa mahasiswa Teknik Mesin tidak tahu atau memang tidak ingin tahu. Bahasa Inggris dipelajari dari SD, SMP, SMU dan mahasiswa karena itu dosen harus tahu bagaimana mengatasi waktu yang sangat limit bahwa hasil dari proses pembelajaran dapat diperoleh optimally.

\section{Rumusan Masalah}

Berdasarkan analisa diatas kami menyimpulkan bahwa ada beberapa problem dengan meningkatkan prestasi mahasiswa sebagai berikut.

1. Bagaimana pengaruh jenis pengetahuan susunan kalimat dalam kemampuan menulis bahasa Inggris.

2. Apakah ada hubungan motivasi dan ketertarikan tentang kecakapan kemampuan menulis Bahasa Inggris.

3. Apakah problem mahasiswa Teknik Mesin selama proses Pembelajaran Bahasa Inggris.

\section{Tujuan penelitian}

Berdasarkan latar belakang tersebut diatas, maka tujuan penelitian yang hendak dicapai adalah sebagai berikut:

1. Untuk mencerdaskan dan mengembangkan pendidikan mahasiswa STT PLN dalam berbahasa Inggris

2. Untuk mengetahuai seberapa jauh mahasiswa STT PLN dalam kemampuan menulis Bahasa Inggris.

\section{Hipotesis}

1. Ada pengaruh jenis pengetahuan kemampuan menulis Bahasa Inggris.

2. Dosen Bahasa Inggris ingin memperbaiki tingkat kecerdasan untuk mampu dalam berbahasa Inggris.

\section{Metode Penelitian dan Pengembangan}

\section{A. Tempat dan Waktu Penelitian}

Penelitian dilaksanakan di STT PLN terhadap mahasiswa dengan jumlah 112 orang sampel yang terbagi 4 kelas yang dilaksanakan pada jadwal perkuliahan Bahasa Inggris yang sedang berlangsung.

\section{B. Metode penelitian}

Yang digunakan adalah metode survey dengan pendekatan korelasional .Peneliti menggunakan tiga macam instrumen yang berbentuk soal test pilihan ganda yang disusun berdasarkan indikator - indikator yang ada dalam variabel penelitian untuk mengukur (1) Penguasaan kosa kata (2) penguasaan kalimat (3) penguasaan kosa kata dan kalimat Unit analisis dalam penelitian ini adalah mahasiswa STT PLN Jakarta.

Konstelasi hubungan ketiga variabel penelitian ini ditunjukan dalam gambar 1 . sebagai berikut :

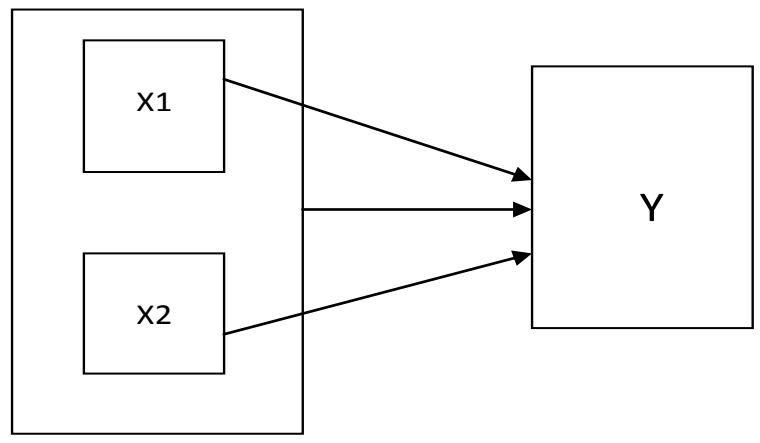

Gambar 1. Konstelasi Model Hubungan Variabel Penelitian

Keterangan :

Y : Variabel terikat (kecakapan menulis / writing skill)

$\mathrm{X} 1$ : Variabel bebas 1 (jenis pengetahuan / genre knowledge )

$\mathrm{X} 2$ : Variabel bebas 2 ( susunan kalimat/ sentence structure )

\section{Populasi dan teknik pengambilan sampel}

1. Populasi penelitian

Populasi adalah wilayah generalisasi yang terdiri atas subject atau object yang mempunyai kwalitas dan karakteristik tertentu yang diterapkan oleh peneliti untuk dipelajari dan kemudian ditarik kesimpulan.Sedang sampel adalah bagian dari jumlah dan karakteristik yang dimiliki oleh populasi (sugiyono : 2009.61-62) 
Populasi penelitian ini adalah mahasiswa ber jumlah 112 orang

Tabel 5.1 mahasiswa STT PLN

\begin{tabular}{|c|c|c|}
\hline No & Nama kampus & Jumlah Mahasiswa \\
\hline 1 & Kelas B/S1 & 25 \\
\hline 2 & Kelas B/D3 & 25 \\
\hline 3 & Kelas A/S1 & 27 \\
\hline 4 & kelasB /S1 & 35 \\
\hline \multicolumn{2}{|c|}{ Total } & 112 \\
\hline
\end{tabular}

2. Teknik pengambilan sampel

Dengan melihat tabel diatas, sampel diambil dengan cara acak dan berstrata sama sebanyak dua kali dengan menggunakan daftar hadir ( absensi ) yang mempunyai angka ganjil dan angka genap. Hal ini sesuai dengan pendapat Hadi (2003:73) yang mengatakan bahwa tidak ada aturan yang jelas tentang jumlah sampel yang dipersyaratkan untuk penelitian, tetapi cara ini menunjukan adanya sampling acak sederhana dan proporsional.

\section{Teknik pengumpulan data}

Pengumpulan data dilakukan pada mahasiswa STT PLN yang menjadi sampel penelitian .Adapun teknik yang digunakan yaitu dengan cara memberikan pilihan ganda untuk mengetahui (1) penguasaan kosa kata (2) penguasaan kalimat (3) penguasaan kosa kata dan kalimat.

\section{Kalibrasi (uji coba Instrumen)}

1. Pengujian validitas (kesahihan)

Sebelum digunakan instrumen diujikan. Kesahihan atau validitas butir soal untuk soal berbentuk pilihan ganda diuji dengan menggunakan koefisien korelasi biserial (safari,2004:71) dengan rumus :

$r_{b i s}(i)=\left(\frac{X_{i}-X_{t}}{s_{t}}\right) \sqrt{\frac{P_{i}}{Q_{i}}} ;$ dimana

Koefisien korelasi biserial antara skor butir soal nomor i dengan skor total.

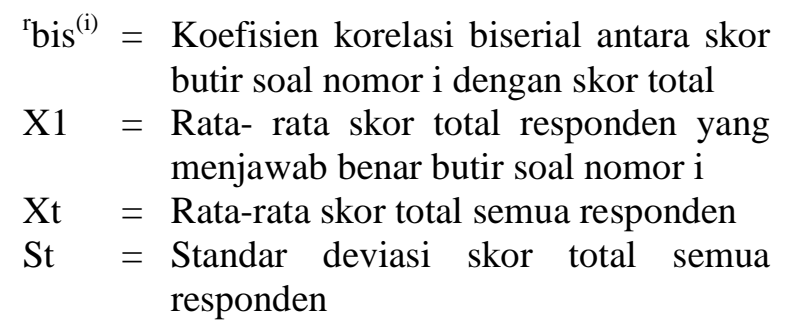

$\mathrm{Pi}=$ Proporsi jawaban benar untuk butir soal nomor i

Qi = Proporsi jawaban salah untuk butir soal nomor i

2. Pengujian reliabilitas (keterhandalan)

Keterhandalan (reliabilitas) instrumen untuk soal pilihan ganda diuji dengan menggunakan Kuder Richardson 20 (safari, 2004:4) dengan rumus

$r_{K R}=\frac{k}{k-1}\left(1-\frac{\sum P i Q i}{S t^{2}}\right) ;$ dimana

${ }^{\mathrm{r}} \mathrm{kR}=$ Koefisien reliabilitas tes

$\mathrm{k}=$ Banyaknya butir soal

$\mathrm{St}^{2}=$ Varians skor total

$\mathrm{PiQi}=$ Vvarians skor butir

$\mathrm{Pi}=$ Proporsi jawaban benar untuk butir $\mathrm{i}$

Qi = Proporsi jawaban salah untuk butir i

Untuk menentukan reliabilitas perangkat soal tersebut digunakan taraf signifikan 5\% pada uji satu pihak dan df (derajat kepercayaan) $=n-2$ perangkat soal dikatakan reliable jika t hitung $>$ $\mathrm{r}$ tabel, $\mathrm{a}=5 \%, \mathrm{n}=$ jumlah anggota sample. Menurut Anas Sudijono( 2001 : 209 ) dalam pemberian inter hasil terhadap reliabilitas tes (r11 ) pada umumnya digunakan patokan sebagai berikut :

1. Apabila $r_{11}$ sama dengan atau lebih besar dari 0,70 berarti tes reliable

2. Apabila $\mathrm{r}_{11}$ lebih kecil 0,60 berarti test tidak reliable

Hasil perhitungan reliabilitas dengan Ms Excel diperoleh hasil 0,90 yang artinya perangkat soal sangat variable.

3. Instrumen Penguasaan kalimat $\left(\mathrm{X}_{2}\right)$

a. Definisi Konseptual

Penguasaan kalimat $\left(\mathrm{X}_{2}\right)$

Penguasaan kalimat adalah jika seseorang memahami hakikat kalimat terlebih dahulu ialah satuan bahasa terkecil dalam wujud lisan maupun tulisan yang memiliki sekurang kurangnya satu subject (S) dan satu perikat $(\mathrm{P})$. Selain dari itu dalam penguasaan kalimat jika seseorang memahami bahwa kalimat mengandung suatu pikiran dan pesan yang lengkap. Memahami klasifikasi kalimat dari segi jumlah dan jenis klausa seperti kalimat tunggal, kalimat tersusun, kalimat majemuk. 


\section{b. Definisi operasional}

Penguasa kalimat adalah skor yang diperoleh dari responden yang menggunakan perakangkat soal tentang penguasaan kalimat yang diberikan kepada mahasiswa dengan indikator kalimat sebagai kesatuan yang terdiri atas klausa yang ditandai dengan intonasi final dan dapat berdiri sendiri bila diperlukan dilengkapi dengan konjungsi .Dalam hal ini berhubungan dengan hakikat kalimat, jenis kalimat, struktur kalimat dan selekta kalimat.

c. Kisi- kisi Instumen

d. Uji instrumen Penguasaan kalimat

a. Pengujian validitas (kesahihan)

b. Pengujian eliabilitas (keterhandalan )

\section{E. Teknik Analisa Data}

\section{Teknik Analisis Deskriptif}

Teknik analisis deskriptif adalah pengujian data hasil penelitian yang dilakukan dengan menyajikan data dalam bentuk perhitungan statistik dasar yang meliputi tabel distribusi frekwensi, histogram, nilai rata-rata, median .modus, simpangan baku dengan dengan rumusan sebagai berikut :

a. $\quad$ Rata-rata $=\frac{\sum X}{n}$

keterangan : $\quad \mathrm{x}=$ rata-rata

$\mathrm{x}=$ jumlah tiap data

$\mathrm{n}=$ jumlah data

b. $\quad$ Median $=M e=1 / 2(n+1)$ dimana $n=$ jumlah data

c. $\quad$ Modus $=b+P\left(\frac{b 1}{b 1+b 2}\right)$

Keterangan :

Mo $=$ Nilai modus

$\mathrm{b}=$ batas bawah nilai yang mengandung nilai modus

$\mathrm{p} \quad=$ panjang kelas nilai modus

$\mathrm{b} 1=$ sellisih antara frekwensi modus dengan frekwensi sebelumnya

b2 = selisih antara krekwensi modus dengan frekwensi sesudahnya.

d. Simpangan baku

$$
\sqrt{\frac{\sum x^{2}-\left(\sum x\right)^{2}}{n(n-1)}} \text { atau } \mathrm{s}=\sqrt{\frac{\sum x^{2}}{n-1}}
$$

Analisa deskriptif dilakukan untuk memperoleh gambaran tentang motivasi belajar, persepsi mahasiswa atas lingkungan mahasiswa dan prestasi belajar mahasiswa.

2. Uji persyaratan data

Uji ini dilakukan untuk mengetahui apakah data dapat digunakan untuk analisis dan perhitungan selanjutnya.Yang digunakan dalam uji persyaratan data yaitu:

a. Uji normalitas

Pengujian ini bertujuan untuk mengetahuin apakah data berdistribusi normal atau tidak. Model regresi yang baik adalah distribusi data normal atau mendekati normal. Pengujian normalitas data dilakukan dengan menggunakan uji kolmogorov.Pengujian yang menunjukan data yang normal diperoleh apabila nilai signifikansi > 0,05 ( singgih santosa dalam bukunya yang berjudul SPSS 17. Statistical product and services solusions,2000:314 )

\section{b. Uji linearitas}

Hasil uji linearitas yang digunakan untuk menguji lincar tidaknya data yang dianalisis yaitu variabel independen terhadap variabel dependen.Kriteria pengujian jika angka pada deviation from linearity lebih besar dari 0,05 (> 0,05 ), berarti hubungan antara variabel independen dan variabel dependen adalah linear. Berdasarkan hasil perhitungan probabilitas sig. Perhitungan selanjutnya dilakukan dengan menggunakan spss 17.

c. Uji homoginitas

Hasil uji homoginitas yang digunakan untuk menguji homogen tidaknya data yang dianalisis yaitu variabel independen terhadap variabel dependen. Kriteria pengujian jika nilai sig pada test of homogenity of variances lebih besar dari 0.05 ( > 0,05 ). Berarti data berasal dari populasi yang homogen. Berdasarkan hasil perhitungan probalitas sig.

Perhitungan selanjutnya dilakukan dengan menggunakan program spss 17.

\section{Uji hipotesis}

Teknik analisis data yang penulis gunakan adalah regresi ganda (menggunakan program spss) analisis regresi ganda adalah semua alat analisis peramalan nilai pengaruh dua variabel bebas atau lebih terhadap satu variabel terikat, untuk membuktikan ada atau tidaknya pengaruh antara dua variabel bebas atau lebih dengan variabel terikat. 
Rumus regresi berganda :

$\hat{\mathrm{Y}}=\mathrm{a}+\mathrm{b}_{1} \cdot \mathrm{X}_{1}+\mathrm{b}_{2} \cdot \mathrm{X}_{2}+\mathrm{e}_{\mathrm{e}}$

Dimana :

$\hat{\mathrm{Y}}=$ kemampuan memba pemahaman

$\mathrm{b}=$ koefisien variable $\mathrm{X}$

$\mathrm{X}_{1}=$ variable penguasaan kosa kata

$\mathrm{X}_{2}=$ variable penguasaan kalimat

$\mathrm{a}=$ konstanta

\section{B. Pengujian persyaratan analisis.}

Pengujian analisis regresi linear, baik lenear sederhana maupun ganda. Harus memenuhi beberapa persyaratan analisis, Persyaratan analisis tersebut adalah sebagai berikut :

1. Sampel yang berupa pasangan data $x_{1}$ dan $\mathrm{x}_{2}$ harus diambil acak dan memenuhi sampel minimum.

2. Untuk setiap kelompok harga predikator $\mathrm{x}_{1}$ yang diberikan, respons respons $\mathrm{x}_{2}$ harus independen dan berdistribusi normal .

3. Untuk setiap kelompok harga predikator $\mathrm{x}_{1}$, variabel s harus homogen (sama)

4. Bentuk regresi adalah linier.

Persyaratan pertama telah terpenuhi, sebab sampel penelitian ini telah diambil acak dengan ukuran sampel sebanyak 40 orang. Sementara itu untuk persyaratan keempat yakni syarat bentuk linear persamaan regresi pengujiannya dilakukan secara bersama sama dengan pengujian hipotesis.

Namun data tersebut baru dinyatakan valid untuk tujuan pengujian hipotesis apabila data taksiran, persamaan regresi dan homogenitas.
Uji normalitas dilakukan dengan metode tersebut mempunyai asumsi distribusi normal dan data tersebut bersifat homogen.

Karenanya perlu dilakukan pengujian normalitas galat kolmogorov-smirnov dengan bantuan program spss versi 17 .

\section{Pengujian hipotesis penelitian}

Untuk hipotesis tersebut dilakukan pengujian dengan menyusun, koefision korelasi, uji signifikansi koefisien korelasi dan uji signifikansi koefisien korelasi ganda.

\section{Koefisien korelasi ganda}

Berdasarkan hasil pengolahan data menunjukan bahwa variabel jenis pengetahuan/ genre dan susunan kalimat ataupun sentence structure secara bersama sama mempunyai korelasi ganda dengan variabel student writing skill dalam kemampuan menulis bahasa Inggris sebesar $\mathrm{R}=+0.811$ yang berarti makin tinggi jenis pengetahuan/ genre knowledge dan senten structure/susunan kalimat mahasiswa dalam menulis bahasa Inggris akan diikutin makin tingginya mahasiswa dalam kemampuan kecakapan menulis.

Selanjutnya variabel variabel jenis pengetahuan/genre knowledge dan susunan kalimat /senten structure secara bersama sama dapat menentukan variabel kemampuan mahasiswa dalam menulis bahasa Inggris / student writing skill sebesar 65,8 percent ( $\mathrm{R}$ Square $=0.658$ ). Koefisien korelasi ganda dan koefisien determinasi ini menunjukan tingkat sangat signifikant, karena nilai sig $=0.000<$ 0.01 dan nilai $\mathrm{f}$ hitung $=35.563$.

\begin{tabular}{|l|l|l|l|l|}
\hline \multirow{2}{*}{ Model } & \multicolumn{2}{|c|}{ R } & \multicolumn{1}{c|}{ Rodel summary } \\
\hline 1 & 0,811 & 0.658 & Adjusted R square & $\begin{array}{c}\text { Std Error of the } \\
\text { Estimate }\end{array}$ \\
\hline
\end{tabular}

a. prediktor : (constant) sentence structure, genre knowledge

Pengujian Koefisien Korelasi Ganda ANOVA

\begin{tabular}{|c|c|c|c|c|c|}
\hline Model & $\begin{array}{l}\text { Sum of } \\
\text { squares }\end{array}$ & Df & Mean Squar & $\mathrm{F}$ & Sig \\
\hline $\begin{array}{l}\text { 1. Regression } \\
\text { Residual } \\
\text { Total }\end{array}$ & $\begin{array}{l}4643.726 \\
2415.649 \\
7059.375\end{array}$ & $\begin{array}{l}2 \\
37 \\
39\end{array}$ & $\begin{array}{l}2321.863 \\
65.288\end{array}$ & 35.563 & 0.000 \\
\hline
\end{tabular}

a. Predikator ( constant) sentence structure,genre knowledge

b. Dependent variabel : writing skill ( kemampuan menulis ) 
Koefisien Regresi Ganda dan tingkat significansinya

Coefficients

\begin{tabular}{|l|c|c|c|c|c|}
\hline \multicolumn{1}{|c|}{ Model } & \multicolumn{2}{|c|}{$\begin{array}{c}\text { Unstandardized } \\
\text { Coefficients }\end{array}$} & $\begin{array}{c}\text { Standardized } \\
\text { Coefficients }\end{array}$ & $\mathrm{t}$ & Sig \\
\hline & $\mathrm{B}$ & Std Error & Beta & & \\
\hline 1 ( Constant ) & -34.466 & 11.537 & & -2.987 & 0.005 \\
Genre knowledge & 0.793 & 0.164 & 0.559 & 4.836 & 0.000 \\
Sentence structure & 0.602 & 0.197 & 0.354 & 3.058 & 0.004 \\
\hline
\end{tabular}

a. Dependent Variable writing skill ( kemampuan menulis )

$$
\begin{array}{llll}
\hat{\mathrm{Y}}=-34,466+0.793 \mathrm{X}_{1}+0.602 \mathrm{X}_{2} \\
\mathrm{t}_{\text {hitung }}= & 4.836 & 3.058 \\
\mathrm{Sig}= & 0.000 & 0.004
\end{array}
$$

Berdasarkan tabel diatas persamaan regresi ganda menunjukan bahwa hipotesis statistik Ho : tidak terdapat pengaruh variabel

\section{Pembahasan hasil penelitian}

Penelitian ini untuk mengetahui pengaruh jenis pengetahuan / genre knowledge ( X1 ) dan susunan kalimat ( $\mathrm{x} 2$ ) terhadap kemampuan mahasiswa STT PLN dalam menullis bahasa Inggris.( y )

\section{Hipotesis 1}

Pengaruh jenis pengetahuan dan kecakapan susunan kalimat /the effects genre knowledge and sentence structure bersama sama terhadap kemampuan menulis bahasa Inggris mahasiswa teknik mesin.

Persyaratan regresi telah memenuhi persyaratan yang diperlukan antara lain variabel dependen mengikuti distribusi normal, dan hasil uji linearitas diperoleh persamaan regresi variable dependent terhadap variable independent adalah linier.

Hasil pengujian diperoleh $\mathrm{F}$ hitung $=$ 35.563 dan $\mathrm{F}$ table pada $\mathrm{a}=0.05 \mathrm{df} 1=\mathrm{k}=2$, df $2=\mathrm{n}-\mathrm{k}-1=37$ adalah 3.25 ( $\mathrm{n}$ adalah jumlah responden dan $\mathrm{k}$ adalah jumlah variable bebas ), maka $\mathrm{F}$ hitung > F table.

Hal ini menunjukan variable jenis pengetahuan dan kecakapan susunan kalimat secara bersama-sama memiliki pengaruh yang signifikan terhadap variable mahasiswa teknik mesin dalam kemampuan menulis bahasa Inggris.

Selanjutnya berdasarkan persamaan regresi ganda dapat diartikan setiap kenaikan satu unit jenis pengetahuan dan sekaligus dengan kenaikan satu unit variable kecakapan susunan kalimat akan diikuti dengan kemampuan menulis mahasiswa teknik mesin sebesar 1.395 unit.

Hasil pengujian hipotesis diatas menunjukan bahwa telah terbukti terdapat pengaruh langsung variable jenis pengetahuan terhadap variable kemampuan menulis bahasa Inggris , hal yang sama untuk variable kecakapan dalam menyusun kalimat.

Selanjutnya untuk bersama sama variable jenis pengetahuan dan variable kecakapan susunan kalimat memberikan konstribusi terhadap variable mahasiswa teknik Mesin sebesar 65.8 persent.Berdasarkan besaran $\mathrm{F}$ hitung dan tingkat signifikansinya menunjukan bahwa secara berturutan menunjukan bahwa secara berturutan menunjukan pertama adalah penguasaan jenis pengetahuan kedua penguasaan kecakapan susunan kalimat.

\section{Hipotesis 2}

Pengaruh jenis pengetahuan terhadap mahasiswa teknik mesin dalam kemampuan menulis bahasa Inggris.

Berdasarkan hasil pengujian diperoleh $t$ hitung $=4.836>\mathrm{t}$ hitung $=1.69$, maka dapat dinyatakan terdapat pengaruh yang signifikan variable jenis pengetahuan terhadap variable kemampuan menulis bahasa Inggris teknik mesin.Setiap kenaikan satu unit jenis pengetahuan akan diikuti dengan kenaikan kemampuan menulis dalam bahasa Ingris sebesar 0.793 unit.ceteris variabus variable kecakapan susunan kalimat tidak berubah.

Menurut sintetis teori yang ada diatas kemampuan menulis dalam bahasa Inggris adalah ketrampilan seseorang dalam 
menggambarkan kehidupan sehari hari dengan ceritera dari awal sampai akhir.

Unsur unsur pembangunan cerpen adalah :

1. Unsur pembangunan dari dalam yang disebut unsur intrinsik berupa : tema alur, pernokohan, setting, sudut pandang penceritaan, dan bahasa.

2. Unsur pembangun dari luar yang disebut unsur ekstrinsik , antara lain: latar belakang pengarang, latar belakang penulisan dan gejala atau situasi sosial masyarakatdalam menerima cerpen.

Sedangkan jenis pengetahuan/ genre knowledge pada hakekatnya merupakan suatu kata yang bermakna yang dapat digunakan dalam segala hal, baik formal maupun nonformal yaitu baik kata byang bermakna denotasi maupun katayang bermakna konotasi.Dalam menulis cerpen dibutuhkan penguasaan makna kata.

Dengan demikian dapat diartikan semakin baik jenis pengetahuan mahasiswa maka dalam kemampuan menulis bahasa Inggris mahasiswa teknik mesin STT PLN akan semakin baik juga.

Dari informasi kuantitatif dan teori tersebut maka peneliti menyimpulkan bahwa terdapat pengaruh yang signifikan jenis pengetahuan terhadap mahasiswa teknik mesin dalam menulis bahasas Inggris.

\section{Hipotesis 3}

Pengaruh kecakapan susunan kalimat terhadap kemampuan mahasiswa teknik mesin dalam menulis bahasa Inggris.

Berdasarkan hasil pengujian diperoleh $\mathrm{t}$ hitung $=3.058>\mathrm{t}$ hitung $=1.69$ maka dapat dinyatakan terdapat pengaruh yang signifikan variable kecakapan susunan kalimat dengan variable kemampuan mahasiswa teknik mesin dalam menulis bahasa inggris.

Setiap kenaikan satu unitkecakapan susunan kalimatakan diikuti dengan kenaikan mahasiswa teknik mesin dalam penulisan bahasa Inggris sebesar 0.602 unit, ceteris paribus atau variable jenis pengetahuan tidak berubah.

Hasil penelitian menunjukan bahwa terdapat pengaruh yang signifikan kecakapan susunan kalimat tehadap mahasiswa teknik mesin dalam penulisan bahasa Ingris.

Sedangkan kalimat majemuk adalah hasil dari upaya memilih kata tertentu untuk dipakai dalam satu tuturan bahasa yang tepat untuk menyatakan sesuatu sehingga terjadi kebenaran dalam penguasaan kalimat majemuk dalam kalimat dan tepat untuk situasi tertentu.
Dalam menulis akan berhadapan dengan masalah susunan kalimat.

Dengan demikian dapat diartikan semakin baik penguasaan susunan kalimat maka mahasiswa teknik mesin dalam membuat tulisan semakin baik juga.

Dari informasi kuantitatif dan teori tersebut maka peneliti beramsumsi bahwa terdapat pengaruh yang signifikansusunan kalimat terhadap kemampuan menulis mahasiswa teknik mesinSTT PLN.

Koefisen korelasi setelah pengaruh variable susunan kalimat dihilangkan dari hubungan linear antara variable kemampuan menulis bahasa inggris mahasiswa teknik mesin dan variable jenis pengetahuan. Angka ini adalah menunjukan angka koefsien korelasi yang sebenarnya dalam keterkaitan hubungan antara variable dependent mahasiswa teknik mesin dalam kemampuan menulis bahasa Inggris dengan variable variable independen jenis pengetahuan dan kecakapan susunan kalimat.

\section{Kesimpulan dan saran.}

\section{A. Kesimpulan}

Penelitian bertujuan untuk mengetahui pengaruh jenis pengetahuan dan kecakapan susunan kalimat secara sendiri sendiri maupun secara bersama sama dengan mahasiswa teknik mesin STT PLN.

Diperoleh kesimpulan sebagai berikut:

1. Terdapat pengaruh yang signifikan dan kecakapan susunan kalimat secara bersama sama terhadap mahasiswa teknik mesin STT PLN dalam kemampuan menulis bahasa Inggris.dengan koefsien korelasi ganda Ry $12=0.811$.

Jenis pengetahuan dan kecakapan susunan kalimat secara bersama sama menyumbang sebesar $65.8 \%$ terhadap variasi mahasiswa teknik mesin dalam menulis bahasa Inggris melalui persamaan regresi ganda $=-34.466$ $+0.793 \times 1+0.602 \times 2$ yang signifikan pada taraf 0.05. Hasil pengujian signifikansi diperoleh $\mathrm{F}$ hitung $=35.563>\mathrm{F}$ tabel 3.25.

2. Terdapat pengaruh yang signifikan jenis pengetahuan terhadap kemampuan mahasiswa teknik mesin dalam menulis bahasa Inggris.

Variable jenis pengetahuan secara efektif menyumbang sebesar $64.3 \%$ terhadap variasi kemampuan mahasiswa teknik mesin dalam penulisan bahasa inggris. 
Hasil pengujian signifikan diperoleh $\mathrm{t}$ hitung (4.836) > t tabel ( 1.69 ) pada taraf nyata $5 \%$.

3. Terdapat pengaruh yang signifikan antara kecakapan susunan kalimat terhadap kemampuan mahasiswa teknik mesin STT PLN dalam menulis bahasa inggris.

Variabel kecakapan susunan kalimat secara efektif menyumbang sebesar $35.7 \%$ terhadap variasi kemampuan mahasiswa teknik mesin dalam menulis bahasa Inggris. Hasil pengujian signifikasi diperoleh $\mathrm{t}$ hitung ( 3.058 ) > t tabel ( 1.69 ) pada taraf nyata $5 \%$.

\section{Saran}

1. Hasil penelitian ini menemukan bahwa mean adalah 60,63 dan masih ada35 \% kemampuan mahasiswa teknik mesin dalam menulis bahasa Inggris berada dibawah nilai rata rata.

2. Peningkatan kemampuan mahasiswa teknik mesin dalam menulis bahasa inggris ditempuh dengan meningkatkan jenis pengetahuan dan kecakapan susunan kalimat secara lebih baik lagi.

\section{DAFTAR PUSTAKA}

1. Douglaas Brown, the principle of language learning and teaching.

2. Marcella Frank, Modern English : reference Guide

3. Marcella Frank, Modern English : an Exercise book 11

4. Ujang suparman, M.Ph.D : psycholinguistik the teory of language Acquisition.

5. Alia Oshima Ann Hogue : Writing Academic English

6. Bill Cope and Mary Kalantzis : The power of literacy-genre approach To teaching writing

7. John M Swales : Genre Analysis- English in Academic and research settings

8. Erick Glendinning and Hellen Mantell : Write ideas - in intermediate Course in writing skill .

9. Otong Setiawan Djuharie : genre

10. H.Douglas Brow : Teaching by pronciple An interactive Approach to language pedagogy second edition.

11. Jack C Richards and thedores Rosgers : Approaches and Methods in language Theaching.
12. George E Wishon Julia M Burks : Let's write English

13. Pardiyono.Mpd : Teaching Genre based writing. 